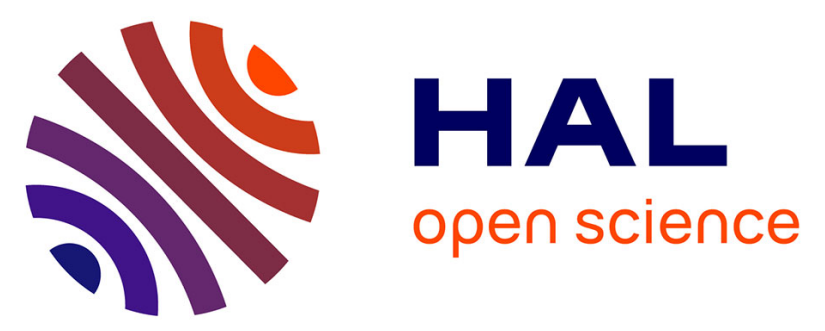

\title{
Beige differentiation of adipose depots in mice lacking prolactin receptor protects against high-fat-diet-induced obesity.
}

\author{
Julien Auffret, Say Viengchareun, Nadège Carre, Raphaël G. P. Denis,
} Christophe Magnan, Pierre-Yves Marie, Adeline Muscat, Bruno Fève, Marc

Lombès, Nadine Binart

\section{To cite this version:}

Julien Auffret, Say Viengchareun, Nadège Carre, Raphaël G. P. Denis, Christophe Magnan, et al.. Beige differentiation of adipose depots in mice lacking prolactin receptor protects against high-fat-dietinduced obesity.: PRLR deficiency and beige adipocyte. FASEB Journal, 2012, 26 (9), pp.3728-37. 10.1096/fj.12-204958 . inserm-00696058

\section{HAL Id: inserm-00696058 https://www.hal.inserm.fr/inserm-00696058}

Submitted on 16 May 2014

HAL is a multi-disciplinary open access archive for the deposit and dissemination of scientific research documents, whether they are published or not. The documents may come from teaching and research institutions in France or abroad, or from public or private research centers.
L'archive ouverte pluridisciplinaire HAL, est destinée au dépôt et à la diffusion de documents scientifiques de niveau recherche, publiés ou non, émanant des établissements d'enseignement et de recherche français ou étrangers, des laboratoires publics ou privés. 
Beige differentiation of adipose depots in mice lacking prolactin receptor protects against high fat diet-induced obesity

\section{Julien Auffret ${ }^{*}$, , Say Viengchareun" ${ }^{*}$, Nadège Carré ${ }^{*}$, , Raphaël G. P. Denis ${ }^{\mathrm{II}}$, Christophe Magnan ${ }^{\mathbb{I}}$, Pierre-Yves Marie ${ }^{\ddagger}$, Adeline Muscat ${ }^{\S}$, Bruno Fève ${ }^{\S}$,} Marc Lombès ${ }^{*} ;, \#$ and Nadine Binart ${ }^{*,+, \#, 1}$

* Inserm U693, Le Kremlin-Bicêtre, F-94276, France;

${ }^{\dagger}$ Univ Paris-Sud, Faculté de Médecine Paris-Sud, UMR-S693, Le Kremlin-Bicêtre, F-94276, France;

${ }^{\text {II }}$ Univ Paris Diderot, Sorbonne Paris Cité, CNRS EAC 4413, Equipe Homéostasie Energétique et Régulations nerveuses et endocrines, Paris, F-75025, France;

‡Inserm U961, CHU-Nancy, Nancy, F-54000, France;

${ }^{\S}$ UMR-S 938, Faculté de Médecine Pierre et Marie Curie, site St Antoine, Paris F-75012, France;

\# Assistance Publique-Hôpitaux de Paris, Hôpital de Bicêtre, Service d'Endocrinologie et des Maladies de la Reproduction, Le Kremlin Bicêtre F-94275, France.

\section{${ }^{1}$ Correspondence:}

Inserm U693, Le Kremlin-Bicêtre, F-94276, France

E-mail: nadine.binart@inserm.fr

Fax: 33149596732 
Short title: PRLR deficiency and beige adipocyte

Nonstandard abbreviations used in the manuscript:

PRL, prolactin; PRLR, prolactin receptor; PET, positron emission tomography; BAT, brown adipose tissue; WAT, white adipose tissue; PRDM16, PR domain containing 16; PGC1 $\alpha$, peroxisome proliferator-activated receptor $\gamma$ coactivator $1 \alpha$; FOXC2, forkhead box protein $\mathrm{C} 2$; Rb, retinoblastoma; IL-6, interleukin-6; HFD, high fat diet; SC, show diet; FDG, fluoro-2-deoxyglucose; ADR $\beta 3$, $\beta 3$-adrenoceptor; ZFP423, 30-zinc finger transcription factor; UCP1, uncoupling protein 1; C/EBP $\beta$, CCAAT/enhancer-binding protein $\beta$; PPAR $\gamma$, peroxisome proliferator-activated receptor $\gamma$; SREBP1, sterol regulatory element-binding protein 1; PBS, phosphate buffered saline. 
ABSTRACT Stimulating conversion of white fat to metabolically active adipocytes (beige fat) constitutes a promising strategy against weight gain and its deleterious associated-disorders. We provide direct evidence that prolactin (PRL), best known for its actions on the mammary gland, plays a pivotal role in energy balance through the control of adipocyte differentiation and fate. Here we show that lack of prolactin receptor (PRLR) causes resistance to high fat diet-induced obesity due to enhanced energy expenditure and increased metabolic rate. Mutant mice displayed reduced fat mass associated with appearance of massive brown-like adipocyte foci in perirenal and subcutaneous but not in gonadal fat depots under high fat diet. Positron emission tomography imaging further demonstrated the occurrence of these thermogenic brown fat depots in adult mice, providing additional support for recruitable brown-like adipocytes (beigeing) in white fat depots. Consistent with the activation of brown adipose tissue, PRLR inactivation increases expression of master genes controlling brown adipocyte fate (PRDM16) and mitochondrial function (PGC1 $\alpha$, UCP1). Altered $p R b / F o x c 2$ expression suggests that this PRL-regulated pathway may contribute to beige cell commitment. Together, these results provide direct genetic evidence that PRLR affects energy balance and metabolic adaptation in rodents via effects on brown adipose tissue differentiation and function.

Key Word: thermogenesis, prolactin, adipocyte 


\section{INTRODUCTION}

Body weight is finely regulated through energy expenditure, nutritional, neuronal and hormonal signals. Organs such as brain, pancreas, liver, skeletal muscle and adipose tissue can integrate these endogenous or environmental factors to ensure metabolic homeostasis. Prolactin (PRL), initially identified for its ability to stimulate mammary gland development and lactation was thereafter suspected to exert pleiotropic functions, including effects on growth, development, immunoregulation, brain and behavior, electrolyte and energy homeostasis (1-3). However, the physiological relevance of most of these functions in humans remains an open issue.

The biological actions of PRL are mediated by its interaction with PRL receptor (PRLR), a member of the cytokine receptor superfamily $(4,5)$. Compared to growth hormone and its cognate receptor, the actions of PRL and PRLR on metabolic homeostasis under non-lactating conditions have received less attention. However, within the last decade, a wealth of experimental data has documented the potential role of PRLR signaling in body weight regulation, pancreas development and insulin secretion, and adipose tissue physiology (3). Regarding body weight regulation, some conflicting results have emerged from $\mathrm{PRLR}^{-/-}$mice while decreased weight gain was observed in 8-9 mo-old PRLR ${ }^{-/-}$females (6). This was not confirmed by subsequent studies in younger animals $(7,8)$.

Interestingly, several reports described higher body weight in humans with prolactinoma, but the mechanisms underlying this association are poorly understood and likely pleiotropic (9). Some authors suggest that weight loss in humans occurs after complete or near normalization of serum PRL with dopamine agonists (10). Several lines of evidence support a direct role for PRL in adipogenesis. PRL enhances the expression of $C / E B P \beta$ and $P P A R \gamma$ in NIH-3T3, two master genes of adipogenesis (11). Lack of PRLR in mice results in an impaired development of both parametrial and subcutaneous adipose tissues associated with a 
lower number of adipocytes without change in their volume (8). PRL signaling also alters lipid metabolism through inhibition of lipoprotein lipase activity in human white adipose tissue and inhibits adipokine release including leptin, adiponectin and IL-6 (12). In addition, PRL potentiates the insulin effect on leptin release in cultured brown adipocytes (13). Most important, PRL signaling is essential for normal perinatal brown adipocyte thermogenesis. Newborn mice lacking PRLR have hypotrophic BAT depots that express low levels of adipogenic markers reducing mouse viability during cold challenge (14). Moreover, immortalized $\mathrm{PRLR}^{-/-}$preadipocytes fail to undergo differentiation into mature brown adipocytes, and could be rescued by reintroduction of PRLR (14). Interestingly, PRL is also released both by primary preadipocytes and adipose explants and its expression changes according to white adipose tissue localization, suggesting a potential autocrine-paracrine loop in a depot specific manner (15).

Although all these experimental data converge to support a physiological role of PRLR in the control of energy homeostasis, the pathophysiological involvement of this receptor on adipocyte plasticity remains unclear. The aim of the present study was to clarify the potential adaptive function of PRL signaling under obesogenic conditions. For this purpose, we subjected $\mathrm{PRLR}^{-/-}$mice to a high fat diet (HFD) for 16 weeks and analyzed their metabolic phenotypes. Remarkably, $\mathrm{PRLR}^{-/-}$mice were highly resistant to HFD-induced obesity, a phenomenon that involves a brown conversion of white fat depots defined as beigeing $(16,17)$. Thus, manipulations of the PRL signaling pathway could hopefully be translated into adjunct therapy to raise energy expenditure and promote weight loss. 


\section{MATERIALS AND METHODS}

Mice

Eight-wk-old PRLR ${ }^{-/-}$and wild type male mice, on a pure $129 / \mathrm{SvJ}$ background, were kept on a 12:12 h light-dark cycle in a temperature-controlled colony room and had ad libitum access to tap water and were challenged for 16 weeks with standard chow (SC) (17\% fat, 23\% protein, 60\% carbohydrates, Harlan, Gannat, France) or high fat diet (HFD) (60\% fat, 20\% protein, 20\% carbohydrates, Research Diets, Denmark) (18). Body weight was measured weekly. Mice were sacrificed and tissues were removed, weighed and used for subsequent gene expression and histological analyses. All procedures were approved by the Ministère de l'Agriculture, France.

\section{Body fat determination}

Body weight composition was evaluated by Dual-Energy X Ray Absorptiometry (DEXA) using a PIXIMUS apparatus (LUNAR Corporation; Madison, WS, USA). Mice were anesthetized by ip injection $(100 \mu \mathrm{l} / 10 \mathrm{~g} \mathrm{BW})$ of a saline mixture containing $0.1 \%$ Xylazin (Rompun, Bayer Pharma; Puteaux, France) and $10 \mathrm{mg} / \mathrm{ml}$ of Ketamin (Imalgène 1000, Merial, Lyon, France). Fat mass and lean masses were calculated according to computerized measurements of Piximus apparatus.

\section{Metabolic parameters exploration}


Mice were analyzed for whole body energy expenditure, and oxygen consumption $\left(\mathrm{VO}_{2}\right)$, food intake ( $\mathrm{g}$ ) and spontaneous activities using calorimetric cages with bedding, and had $a d$ libitum access to food and water (Labmaster, TSE Systems GmbH, Bad Homburg, Germany). Animals were acclimated in individual cages for $48 \mathrm{~h}$ before experiments. Data were recorded every 40 min during the entire experiment. The flow was calibrated with $\mathrm{O}_{2}$ and $\mathrm{CO}_{2}$ mixture of known concentrations before the experiment. Whole energy expenditure was calculated according to the Weir equation. Food and water consumptions were recorded by highly sensitive online feeding and drinking sensors. Each cage enabled tracking of mice with infrared light thus allowing measurement of total activity. The sensors for gases and detection of movement operate efficiently in both light and dark phases, allowing continuous recording. Mice were monitored for body weight and composition at entry and exit of the experiment. Body mass composition (lean tissue mass, fat mass, free water and total water content) was analyzed using an EchoMRI (Whole Body Composition Analyzers, Echo Medical Systems, Houston, USA). Data analysis was performed using extracted value of $\mathrm{VO}_{2}$ consumed, (expressed in $\mathrm{ml} / \mathrm{kg} / \mathrm{h}$ ), and energy expenditure $(\mathrm{kcal} / \mathrm{kg} / \mathrm{h})$.

\section{Plasma measurements}

Blood was collected at sacrifice and plasma insulin from $16 \mathrm{~h}$-fasting mice was measured using the Ultra Sensitive Insulin ELISA kit (Crystal Chem Inc, Downer Grove, USA). Glycemia was determined with Accu-Chek Performa Glucometer (Roche, Bâle, Swisserland). Plasma leptin and resistin were measured using the MADPK-71K kit (Millipore, Molsheim,

France). Total cholesterol levels were determined by enzymatic colorimetric assays (Sobodia, Montbonnot-Saint-Martin, France). 


\section{Homeostasic model assessment (HOMA) determination}

HOMA-IR and HOMA- $\beta$ index were used to quantify insulin resistance and beta cell function, respectively. These indexes were determined as follows: HOMA-IR $=$ (glucose $\mathrm{x}$ insulin $) / 405$ and HOMA- $\beta=(360 \mathrm{x}$ insulin $) /($ glucose -63$) \%$. Fasting glucose and insulin are expressed as $\mathrm{mg} / \mathrm{dL}$ and $\mathrm{mU} / \mathrm{L}$, respectively.

\section{Immunocytochemical and histomorphological procedures}

Tissues were fixed overnight in $4 \%$ paraformaldehyde, dehydrated, embedded in paraffin, and $5-\mu \mathrm{m}$-thick sections were prepared. Sections were permeabilized with $0.1 \%$ Triton $\mathrm{X}-100$ diluted in PBS for $10 \mathrm{~min}$ at room temperature. Sections were rinsed again in PBS, incubated in peroxidase blocking solution $\left(3 \% \mathrm{H}_{2} \mathrm{O}_{2}\right.$ in $\left.\mathrm{PBS}\right)$ for $10 \mathrm{~min}$ to block endogenous peroxidase activity, rinsed in PBS, and incubated with 5\% rabbit serum blocking solution diluted with antibody diluent (Cell Marque, Rocklin, USA) for $1 \mathrm{~h}$ at room temperature. Sections were subsequently incubated overnight at $4^{\circ} \mathrm{C}$ with goat anti-UCP1 antibody (\#sc6528, Santa Cruz Biotechnology, Heidelberg, Germany) diluted 1:100. After washes in PBS, sections were incubated with biotinylated rabbit anti-goat IgG (Jackson ImmunoResearch Laboratories, Inc., Newmarket, UK; diluted 1:500 in blocking solution) for $1 \mathrm{~h}$ at room temperature. Following three rinses in PBS, sections were incubated with HRP-Streptavidin (Vector Laboratories, Peterborough, UK) diluted in PBS for $45 \mathrm{~min}$ at room temperature, rinsed in PBS, incubated in DAB peroxidase substrate solution for $2-5 \mathrm{~min}$, rinsed in distilled water, and coverslipped with glycergel (Dako, Trappes, France). Paraffin-embedded adipose sections were analyzed after hematoxylin and eosin staining. Histological quantification was performed using the ImageJ software (http://rsbweb.nih.gov/ij/). Adipocyte size was 
measured on more than 150 cells per depot and per mouse (5 mice for each group). Percentage of brown adipose tissue (BAT) was determined by calculating BAT area on total area of perirenal adipose tissue.

\section{Western blot analyses}

Total protein extracts were prepared from perirenal WAT isolated from mice. Briefly, WAT was lysed as described previously (13) using the Tissuelyser apparatus (Qiagen Courtaboeuf, France) then $30 \mu \mathrm{g}$ of protein were directly submitted to SDS-PAGE. After protein blotting on an Odyssey® nitrocellulose membrane, blots were incubated for $1 \mathrm{~h}$ at $\mathrm{RT}$ in a blocking buffer (LI-COR, Lincoln, NE, USA) before an overnight incubation at $4^{\circ} \mathrm{C}$ with a sheep antiUCP1 antibody (1:3,000, kindly provided by Pr. D. Ricquier). After washes, blots were incubated with an IRDye 680-conjugated affinity purified anti-sheep IgG second antibody (1:10,000, ABM, Richmond, Canada) for $1 \mathrm{~h}$ at RT. After washes, proteins were visualized with an Odyssey Fc apparatus (LI-COR). GAPDH protein was used as an internal control: blots were incubated for $1 \mathrm{~h}$ at room temperature with rabbit anti-GAPDH $(1: 5,000)$ (Sigma, Saint-Quentin Fallavier, France) followed by $1 \mathrm{~h}$ incubation at RT with an IRDye 800conjugated affinity purified anti-rabbit secondary antibody (1:10,000, Thermo Scientific, Illkirch, France). UCP1 infrared fluorescence was normalized to GAPDH as determined by densitometry using the Image Studio software (LI-COR).

\section{Positron emission tomography}

Positron emission tomography (PET) recording was carried out on 6-mo-old male mice with 2-[ $\left[{ }^{18} \mathrm{~F}\right]$ fluoro-2-deoxyglucose (18F-FDG), a ${ }^{18} \mathrm{~F}$-labeled glucose analogue which is known to be actively trapped by activated BAT in mice $(19,20)$. After $45 \mathrm{~min}$ of cold exposure at $6{ }^{\circ} \mathrm{C}$, 
each of the 4 analyzed mice received around $15 \mathrm{MBq}$ of ${ }^{18} \mathrm{~F}-\mathrm{FDG}$ via tail vein injection, and 45 min later, a whole-body recording was started under continuous anesthesia by isoflurane, (5\% induction, 1-2\% maintenance) and using a dedicated small-animal PET system (Inveon, Siemens, Knoxville, Tennessee, USA). After a 30-min recording period and conventional 3D image-reconstruction, the volume of the foci with high FDG activity were determined using a threshold value of 2 standardized uptake value (SUV): 1) within the interscapular area, which is known to be a depot of BAT in normal mice $(19,20)$, and 2) along the remaining part of the dorsal walls from the thorax and abdomen and thus, in sites known to normally involve WAT in normal conditions.

\section{Gene expression analyses}

Quantitative real-time PCR was performed as described previously (14). After DNAse I treatment, RNA was reverse-transcribed and used for quantitative RT-PCR (qRT-PCR) using the Power SYBR ${ }^{\circledR}$ Green PCR Master Mix (Applied Biosystems). Final primer concentrations were $300 \mathrm{nM}$ (see Table 1 for primer sequences). Reaction parameters were carried out on a StepOne ${ }^{\mathrm{TM}}$ Real-Time PCR System (Applied Biosystems). Relative expression within a given sample was calculated as a ratio (amol of specific gene/fmol of $18 \mathrm{~S}$ ). Results are means \pm SEM.

\section{Data analysis}

Data are expressed as means \pm SEM. Data were analyzed using a non parametric Mann Whitney test or for multiple comparisons, Kruskal-Wallis test followed by Dunn's post-test as appropriate with use of the computer software Prism 5 (GraphPad Software, San Diego, 
USA). Comparisons between time points were analyzed using linear regression. Statistical significance is indicate $\mathrm{d}$ at $\mathrm{p}$ values $<0.05,0.01$ and 0.001 .

\section{RESULTS}

\section{PRLR $^{-/-}$mice are resistant to high fat diet-induced obesity despite high food intake}

Previous studies on $\mathrm{PRLR}^{-/-}$mice showed a mild body weight difference compared to wild type mice (6). We examined whether this receptor inactivation affects body weight regulation. We found that PRLR knock-out resulted in a small decrease in the body weight gain over the 24 weeks when male mice were maintained on standard chow (SC) (Fig. 1A). To further investigate the metabolic impact of PRL signaling, we subjected the PRLR ${ }^{-/-}$and control mice to a high fat diet (HFD). As expected, 16 weeks of ad libitum HFD feeding caused a sharp increase in body weight in both groups; however, $\mathrm{PRLR}^{-/-}$mice gained $16 \%$ less weight than controls during the same period (Fig. 1A, $<<0.001$ ). This difference of body weight was associated with a profound reduction of adipose mass with no difference in the lean mass as revealed by DEXA method (Fig. $1 B, 1 C \mathrm{p}<0.01$ ). Indeed, examination of body fat mass revealed a marked $40 \%$ reduction of the perirenal adipose pad normalized to body weight in PRLR $^{-/-}$mice (Fig. $1 D, \mathrm{p}<0.01$ ) while gonadal and subcutaneous WAT depots, kidney and spleen weights (Figs. $1 E$ - $H$ ) were similar, pointing to a genotypic and diet-related difference in site-specific adipose depots.

To investigate the mechanisms underlying the resistance to HFD-induced obesity of $\mathrm{PRLR}^{-/-}$mice, we measured behavioral and metabolic adjustments to the diet, given that energy intake should equal energy expenditure to maintain energy homeostasis. As depicted in Fig. $2 A$, over 4 consecutive days in metabolism cages, cumulative food intake on SC was 
significantly increased in PRLR ${ }^{-/}$mice compared to controls, the same trend was observed when animals were HFD fed. No change in locomotor activity was detected between the groups (Supplementary Fig. 1). Oxygen consumption and energy expenditure were significantly increased in $\mathrm{PRLR}^{-/-}$mice as compared to WT mice both under SC and after 16 weeks of HFD feeding regimen (Figs. $2 B$ and $2 C$ ). Under HFD, diet-induced enhancement of metabolic rate and energy expenditure, normalized to lean mass, were calculated at $9.5 \%$ and 9.8\% in control mice, but increased up to $12.8 \%$ and $11.9 \%$ in $\mathrm{PRLR}^{-/-}$mice, respectively. Taken together, our data demonstrate that PRL signaling is involved in normal energy expenditure and body weight regulation.

\section{PRLR $^{-/-}$mice are protected against HFD-induced insulin resistance}

To further assess the impact of PRLR deletion on glucose metabolism, we showed that under HFD, WT mice exhibited a glucose intolerance associated with a drastic increase in plasma insulin levels while PRLR ${ }^{-/-}$mice improved their glucose homeostasis as revealed by normal glycemia with appropriate insulin secretion (Figs. $3 A$ and $3 B$ ). Calculated HOMA-IR and HOMA- $\beta$ indexes provided additional support for the improvement of insulin resistance and the conservation of insulin secretion in the absence of PRLR under HFD (Figs. $3 C$ and $3 D$ ). Leptin levels were elevated after HFD feeding in both groups, but they were significantly lower in the PRLR ${ }^{-/}$mice than in control mice as expected from lesser weight gain (Fig. 3E). Finally, in contrast to WT mice, resistin levels were unchanged in $\mathrm{PRLR}^{-/-}$mice, whatever the diet, excluding a major contribution of this insulin action inhibitor in the prevention of HFDinduced glucose intolerance (Fig. $3 F)$.

\section{BAT-like remodeling of perirenal wat in $\mathrm{PRLR}^{-/-}$mice}


We next explored whether the resistance to HFD-induced body weight gain in $\mathrm{PRLR}^{-/-}$mice was associated with histomorphological modifications of fat depots. Both subcutaneous and gonadal WAT disclosed a marked reduction of adipocyte size in $\mathrm{PRLR}^{-/-}$mice under HFD, consistent with the global decrease in fat mass (Supplementary Fig. 2). This suggests a major impact of PRL signaling on the adipocyte metabolic activity. Several multilocular brown-like adipocytes were detected in perirenal WAT of PRLR ${ }^{-/-}$HFD-fed males (Fig. 4A). In contrast, significantly fewer brown-like adipocytes were found embedded in the perirenal fat depot of PRLR $^{+/+}$HFD-fed mice (Fig. 4A). Quantification of brown-like adipose area in the perirenal tissues showed a dramatic increase of the emergence of browning (Fig. 4B), suggesting that in the absence of PRL signaling, HFD induces BAT-like remodeling of perirenal WAT as revealed by BAT-specific uncoupling protein 1 (UCP1) immunostaining (Fig. 4C). These observations were confirmed by western blot analysis (Fig. 4D) that revealed a three-fold increase of UCP1 protein in perirenal WAT of $\mathrm{PRLR}^{-/-}$mice. Further evidence for increased metabolic activity in $\mathrm{PRLR}^{-/}$mice was provided by imaging using positron emission tomography (PET scan) of 2-[ $\left[{ }^{18}\right.$ F]fluoro-2-deoxyglucose uptake (FDG), a glucose analogue taken up avidly by activated BAT in humans as well as in rodents after a cold challenge $(19,20)$. As illustrated in Fig. 4E, all mice had large foci of high FDG uptake in the upper part of the dorsal body area as visualized on coronal and sagittal sections. PRLR ${ }^{-/}$animals exhibited additional foci of high FDG activity in the sites known to mainly harbor WAT under normal conditions with a calculated FDG activity volume in $\mathrm{PRLR}^{-/-}$animals $(785 \pm 1.35$ $\left.\mathrm{mm}^{3}\right)$ compared to $\mathrm{PRLR}^{+/+}$mice $\left(463 \pm 1.81 \mathrm{~mm}^{3}\right)$.

Among multiple metabolic adaptations, HFD enhances dissipation of chemical energy in the form of heat in brown adipocytes (21). This physiological adjustment is achieved through activation of PGC1 $\alpha$-dependent pathways that leads to mitochondrial biogenesis and 
increased expression of BAT-selective genes (PRDM16, UCP1). To gather insights into adipocyte function and to further evaluate the impact of PRLR on adipocyte differentiation, we assessed the expression of brown and adipogenic markers in different WAT depots. As presented in Fig. 5A, HFD strongly induced PRDM16, PGCl $\alpha, U C P 1$, and adrenoceptor $\beta 3$ $(A d R \beta 3)$ mRNA expression in perirenal WAT of $\mathrm{PRLR}^{-/-}$mice along with the pronounced BAT-like phenotype, contrasting to what was observed under SC. Interestingly, the expression of adipogenic markers such as ZFP423, C/EBP $\alpha$, PPAR $\gamma 2$, and SREBP1 was significantly reduced in WAT depots of $\mathrm{PRLR}^{-/-}$mice as compared to those of WT animals under SC. This impaired expression of adipogenic genes in WAT was rescued after HFD, (Fig. 5B), suggesting that compensatory mechanisms may counteract PRL signaling defects. Interestingly, this adaptive brown like-cell programming is highly dependent on the location of adipose depots, in subcutaneous but not gonadal fat (Supplementary Fig. 3) in accordance with the well-known plasticity of specific fat depot $(22,23)$. Altogether, these data indicate that the lack of PRL signaling selectively facilitates BAT-like remodeling under specific metabolic conditions.

\section{Altered pRb/Foxc2 pathway is a key molecular switch for beige cell emergence}

We next investigated the molecular mechanisms by which the absence of PRL signaling is associated with the emergence of UCP1-expressing beige fat cells and resistance to HFDinduced obesity. We focused our attention on the retinoblastoma protein $(\mathrm{pRb})$, a transcription factor involved in cell cycle, previously reported as a downstream effector of PRL signaling (24). In addition, given that $\mathrm{pRb}$ plays a key role in fate choice of differentiating common mesenchymal precursors toward adipocytes (25), we hypothesized that $\mathrm{pRb}$ could regulate adipocyte differentiation and beige conversion. pRb expression was drastically increased 
upon HFD whatever the genotype (Fig.. 5C upper panel); however, PRLR-/- mice displayed a marked reduction of $\mathrm{pRb}$ expression in perirenal depots as compared to PRLR $+/+$ mice.

We also investigated Foxc2 expression, another important transcriptional factor regulating adipocyte metabolism and mitochondrial function (26). Foxc2 expression was significantly reduced in $\mathrm{PRLR}^{-/-}$mice under $\mathrm{SC}$ as compared to $\mathrm{PRLR}^{+/+}$mice, concomitant with the reduction of adipogenic markers (see Fig. $5 C$ lower panel). In contrast, Foxc2 mRNA levels were greatly enhanced under HFD, consistent with the prominent role of this forkhead transcription factor as a key metabolic regulator of brown adipocytes.

Hence, our experiments demonstrate that in mice lacking PRLR, both perirenal and subcutaneous WAT have acquired a brown fat-like phenotype under HFD referred to as "beigeing". In addition, the coordinated changes in pRb and Foxc2 pathways may constitute a molecular switch for preferential metabolic transdifferentiation in this model.

\section{DISCUSSION}

While PRL is known as the pituitary hormone of lactation, accumulating evidence shows that it exerts pleiotropic effects including growth and metabolic actions (2,3). Here, we demonstrate that PRLR is an important effector modulating adipocyte fate and differentiation with impact on energy homeostasis and adaptive thermogenesis.

Despite increased food intake in both SC and HFD, $\mathrm{PRLR}^{-/-}$mice remained leaner than controls and were protected against HFD-induced obesity with a marked reduction in adiposity, notably in perirenal fat mass. Thus, we hypothesized that change in overall energy expenditure may be at least in part responsible for this phenotype. This was supported by increased $\mathrm{O}_{2}$ consumption and enhanced heat dissipation that were significantly higher in $\mathrm{PRLR}^{-/-}$mice as compared to $\mathrm{PRLR}^{+/+}$mice. The relative resistance to HFD-induced obesity 
was accompanied by a more favorable carbohydrate homeostatic profile in PRLR $^{-/}$mice, consistent with the major implication of PRL signaling in energy balance. However, these changes in whole body homeostasis were likely not sufficient to account for the robust protection against HFD-induced weight gain. Increased energy expenditure through BAT activation constitutes a powerful mechanism by which high calorie intake could be dissipated, thereby defending against obesity (27). Indeed, enhanced conversion of white to thermogenically active adipocytes observed in $\mathrm{PRLR}^{-/-}$mice seems to be the key regulatory event involved in protection against HFD-induced obesity, consistent with a role of PRL signaling in adipocyte fate determination and/or reprogramming.

In accordance with PRL-mediated transcriptional control of proadipogenic factors (11), PRLR deficiency was associated with a down-regulation of key regulators of adipocyte differentiation, whose expressions were restored to similar extent than in WT mice under HFD. Beyond this HFD-induced rescue observed in $\mathrm{PRLR}^{-/-}$mice, the most striking finding is the emergence of BAT within white adipose depots. The question of where beige cells originate remains unresolved. It has been proposed that the adaptive UCP1-expressing brownlike adipose cells that develop in WAT in response to cold exposure or beta-adrenergic stimulation can be derived either from a specialized compartment of committed brown precursors, direct differentiation from white preadipocytes, and/or transdifferentiation from mature white adipocytes (28). Regardless of how they arise and the origin of mesenchymatous precursors (often referred to as $\mathrm{Myf5}^{-}$and $\mathrm{Sca}^{+}$progenitors) $(29,30)$, the development of beige adipocytes (17) in perirenal fat tissue correlates well with protection against obesity in $\mathrm{PRLR}^{-/-}$mice. New advances in identification of cellular lineage specification have highlighted several key regulatory factors in specifying brown fat cell fate including PRMD16, a master co-regulator critical for the commitment towards brown adipocyte lineage $(31,32)$. Loss of PRDM16 from brown fat precursors caused a massive reduction in molecular 
and morphological features of brown adipocytes (33). Conversely, transgenic overexpression of PRDM16 strongly induced the development of brown-like adipocytes in adipose depots (22). Remarkably, under HFD, PRMD16 expression is dramatically induced in the perirenal fat depots as well as in the subcutaneous white fat, associated with a concomitant increase of BAT markers. This is supported by the emergence of UCP1-expressing adipocytes and metabolically active beige cells located in the perirenal and paraspinal areas accounting for the increased metabolic rate in absence of PRLR. Accordingly, PRLR ${ }^{-/-}$mice displayed an increased of $A d R \beta 3$ expression, suggesting that PRL signaling may affect sympathetic nervous system activity and/or nerve fibers infiltration in fat depots. Altogether, these findings demonstrate that PRLR inactivation could lead to the emergence of inducible-brown adipocytes and its associated thermogenesis. Remarkably, this beige reprogramming is genetically determined (markedly in $\mathrm{PRLR}^{-/-}$mice), induced under HFD and more pronounced in specific fat depots. By contrast, the presence of an active PRL signaling could participate to the white adipocyte phenotype maintenance of these fat depots. One question concerns the signaling molecules involved in acquisition of a brown adipose-like phenotype in perirenal depots. $\mathrm{pRb}$ has been suggested to regulate adipocyte differentiation (34). In addition, p107, a member of $\mathrm{Rb}$ family, is also implicated in adipose development. $\mathrm{P} 107^{-/-}$ mice are refractory to HFD-induced fat accumulation associated with an increase of $P G C 1 \alpha$ expression (34). Consistently, marked decrease of $p R b$ expression was found in mice deficient in fsp27, a member of the cide family protein regulating adipose tissue differentiation (35). Gonadal and subcutaneous white fat pads of Fsp $27^{-/-}$mice are reduced in size compared to wild type mice, together with the acquisition of BAT-like phenotype (35). Collectively, these findings underscore the implication of $\mathrm{pRb}$ pathway in adipocyte fate, in accordance with the $\mathrm{pRb}$ defect observed in $\mathrm{PRLR}^{-/-}$fat depots. It was shown that $\mathrm{pRb}$-deficient mouse embryonic fibroblasts exhibited an increased expression of the Forkhead transcription factor Foxc2 that 
accompanied a white to brown adipocyte transdifferentiation (36). Similarly, overexpression of Foxc 2 in adipose tissue leads to a lean and insulin-sensitive phenotype accompanied by an increased BAT-like function due to an enhanced mitochondrial biogenesis through activation of mitochondrial transcription factors $(26,37)$. PRLR ${ }^{-/}$mice under HFD displayed a sharp increase in Foxc2 expression, in agreement with the involvement of pRb/Foxc2 pathway in the "beigeing" conversion. The functional role of PRL signaling seems to be highly dependent upon the developmental stage. Indeed, we have demonstrated that PRLR is pivotal for early development of BAT to support neonatal thermogenesis (14). In contrast, during adulthood, the absence of PRL signaling is associated with beige conversion, most notably as an adaptive mechanism to facilitate high fat-induced thermogenesis. Thus, PRL signaling plays important but changing roles in energy homeostasis during the lifespan. This is reminiscent of the metabolic action of PRL reported in amphibians (38), fish and birds (1) but far extends the pleiotropic function of PRL in mammals. From a metabolic point of view, PRL is critical during gestation and lactation, favoring anabolic lipid storages indispensable for energy needs during these two major physiological periods. Several lines of evidence suggest that in humans, PRL signaling could be involved in energy homeostasis including the orexigenic property of PRL $(39,40)$, the genetic association between PRL and obesity $(41,42)$ and the relationship between hyperprolactinemia and obesity $(43,44)$. Several recent reports confirmed the major role of BAT in the control of energy balance. Thermogenic UCP1expressing cells are found interspersed in adult human subcutaneous fat yet their presence negatively correlates with weight gain and insulin resistance (45-49). It would be relevant to examine whether patients with hyperprolactinemia are less prone to develop a functional BAT in response to cold exposure or overfeeding using PET. In sum, our work demonstrates that mice lacking PRLR are highly resistant to HFD-induced obesity, owing to the emergence of a brown adipose-like phenotype in peculiar white fat depots. This is associated with a 
concomitant increase of PRDM16, PGC1 $\alpha, A d R \beta 3$ and Foxc2 that constitutes a molecular switching mechanism. This in turn converges towards an activation of thermogenic brown capacity with the final increase of UCP1 responsible for heat dissipation and resistance to high calorie weight gain. We thus propose that PRL signaling represents an additional determinant of energy homeostasis during physiological and pathophysiological conditions.

\section{ACKNOWLEDGMENTS}

The authors thank Pr. M. Freemark (Duke University Medical Center, Durham, NC) for helpful discussions of the manuscript, P. Letteron (IFR2 Bichat Medical School, Paris) for his help with DEXA analysis, S. Poussier and F. Maskali for the recording and analysis of FDGPET. We are also grateful to Pr. D. Ricquier (Institut Cochin, Paris) for UCP1 antibody. Calorimetric studies were performed at the Functional \& Physiological Exploration Platform (FPE) of the Unit "Biologie Fonctionnelle et Adaptative" Univ Paris Diderot Sorbonne Paris Cité, BFA, EAC 4413 CNRS. R.G.P.D. received a research fellowship from the Région Îlede-France (CODDIM). J.A. is the recipient of a doctoral fellowship from the Ministère de l'Education Nationale, de la Recherche et de la Technologie, France. This work was supported by grants from ANR 09-BLAN-0246, Inserm and Université Paris-Sud.

\section{REFERENCES}

1. Bole-Feysot, C., Goffin, V., Edery, M., Binart, N., Kelly, P. A. (1998) Prolactin and its receptor: actions, signal transduction pathways and phenotypes observed in prolactin receptor knockout mice. Endocr.Rev. 19, 225-268

2. Goffin, V., Binart, N., Touraine, P., Kelly, P. A. (2002) Prolactin: the new biology of an old hormone. Annu.Rev.Physiol. 64, 47-67

3. Ben Jonathan, N., Lapensee, C. R., Lapensee, E. W. (2008) What Can We Learn from Rodents about Prolactin in Humans? Endocr.Rev. 29, 1-41 
4. Clevenger, C. V., Gadd, S. L., Zheng, J. (2009) New mechanisms for PRLr action in breast cancer. Trends Endocrinol.Metab 20, 223-229

5. Binart, N., Bachelot, A., Bouilly, J. (2010) Impact of prolactin receptor isoforms on reproduction. Trends Endocrinol.Metab 21, 362-368

6. Freemark, M., Fleenor, D., Driscoll, P., Binart, N., Kelly, P. A. (2001) Body weight and fat deposition in prolactin receptor-deficient mice. Endocrinology 142, 532-537

7. Fleenor, D., Oden, J., Kelly, P. A., Mohan, S., Alliouachene, S., Pende, M., Wentz, S., Kerr, J., Freemark, M. (2005) Roles of the lactogens and somatogens in perinatal and postnatal metabolism and growth: studies of a novel mouse model combining lactogen resistance and growth hormone deficiency. Endocrinology 146, 103-112

8. Flint, D. J., Binart, N., Boumard, S., Kopchick, J. J., Kelly, P. (2006) Developmental aspects of adipose tissue in $\mathrm{GH}$ receptor and prolactin receptor gene disrupted mice: site-specific effects upon proliferation, differentiation and hormone sensitivity. J.Endocrinol. 191, 101-111

9. Dos Santos Silva, C. M., Barbosa, F. R., Lima, G. A., Warszawski, L., Fontes, R., Domingues, R. C., Gadelha, M. R. (2010) BMI and Metabolic Profile in Patients With Prolactinoma Before and After Treatment With Dopamine Agonists. Obesity.(Silver.Spring)

10. Kok, P., Roelfsema, F., Frolich, M., van Pelt, J., Stokkel, M. P., Meinders, A. E., Pijl, H. (2006) Activation of dopamine D2 receptors simultaneously ameliorates various metabolic features of obese women. Am.J.Physiol Endocrinol.Metab 291, E1038-E1043

11. Nanbu-Wakao, R., Fujitani, Y., Masuho, Y., Muramatu, M., Wakao, H. (2000) Prolactin enhances CCAAT enhancer-binding protein-beta (C/EBP beta) and peroxisome proliferator-activated receptor gamma (PPAR gamma) messenger RNA expression and stimulates adipogenic conversion of NIH-3T3 cells. Mol.Endocrinol. 14, 307-316

12. Brandebourg, T. D., Bown, J. L., Ben Jonathan, N. (2007) Prolactin upregulates its receptors and inhibits lipolysis and leptin release in male rat adipose tissue. Biochem.Biophys.Res.Commun. 357, 408-413

13. Viengchareun, S., Bouzinba-Segard, H., Laigneau, J. P., Zennaro, M. C., Kelly, P. A., Bado, A., Lombes, M., Binart, N. (2004) Prolactin potentiates insulin-stimulated leptin expression and release from differentiated brown adipocytes. J.Mol.Endocrinol. 33, 679-691

14. Viengchareun, S., Servel, N., Feve, B., Freemark, M., Lombes, M., Binart, N. (2008) Prolactin Receptor Signaling Is Essential for Perinatal Brown Adipocyte Function: A Role for Insulin-like Growth Factor-2. PLoS.ONE. 3, e1535

15. Hugo, E. R., Borcherding, D. C., Gersin, K. S., Loftus, J., Ben Jonathan, N. (2008) Prolactin release by adipose explants, primary adipocytes, and LS14 adipocytes. J.Clin.Endocrinol.Metab 93, 4006-4012

16. Vegiopoulos, A., Muller-Decker, K., Strzoda, D., Schmitt, I., Chichelnitskiy, E., Ostertag, A., Berriel, D. M., Rozman, J., Hrabe, d. A., Nusing, R. M., Meyer, C. W., 
Wahli, W., Klingenspor, M., Herzig, S. (2010) Cyclooxygenase-2 controls energy homeostasis in mice by de novo recruitment of brown adipocytes. Science 328, 11581161

17. Ishibashi, J., Seale, P. (2010) Medicine. Beige can be slimming. Science 328, 1113-1114

18. Ormandy, C. J., Camus, A., Barra, J., Damotte, D., Lucas, B. K., Buteau, H., Edery, M., Brousse, N., Babinet, C., Binart, N., Kelly, P. A. (1997) Null mutation of the prolactin receptor gene produces multiple reproductive defects in the mouse. Genes Dev. 11, 167178

19. Carter, E. A., Bonab, A. A., Hamrahi, V., Pitman, J., Winter, D., Macintosh, L. J., Cyr, E. M., Paul, K., Yerxa, J., Jung, W., Tompkins, R. G., Fischman, A. J. (2011) Effects of burn injury, cold stress and cutaneous wound injury on the morphology and energy metabolism of murine brown adipose tissue (BAT) in vivo. Life Sci. 89, 78-85

20. Fueger, B. J., Czernin, J., Hildebrandt, I., Tran, C., Halpern, B. S., Stout, D., Phelps, M. E., Weber, W. A. (2006) Impact of animal handling on the results of 18F-FDG PET studies in mice. J.Nucl.Med. 47, 999-1006

21. Cannon, B., Nedergaard, J. (2004) Brown adipose tissue: function and physiological significance. Physiol Rev. 84, 277-359

22. Seale, P., Conroe, H. M., Estall, J., Kajimura, S., Frontini, A., Ishibashi, J., Cohen, P., Cinti, S., Spiegelman, B. M. (2011) Prdm16 determines the thermogenic program of subcutaneous white adipose tissue in mice. J.Clin.Invest 121, 96-105

23. Ohno, H., Shinoda, K., Spiegelman, B. M., Kajimura, S. (2012) PPARgamma agonists Induce a White-to-Brown Fat Conversion through Stabilization of PRDM16 Protein. Cell Metab 15, 395-404

24. Schroeder, M. D., Symowicz, J., Schuler, L. A. (2002) PRL modulates cell cycle regulators in mammary tumor epithelial cells. Mol.Endocrinol. 16, 45-57

25. Calo, E., Quintero-Estades, J. A., Danielian, P. S., Nedelcu, S., Berman, S. D., Lees, J. A. (2010) $\mathrm{Rb}$ regulates fate choice and lineage commitment in vivo. Nature 466, 11101114

26. Lidell, M. E., Seifert, E. L., Westergren, R., Heglind, M., Gowing, A., Sukonina, V., Arani, Z., Itkonen, P., Wallin, S., Westberg, F., Fernandez-Rodriguez, J., Laakso, M., Nilsson, T., Peng, X. R., Harper, M. E., Enerback, S. (2011) The adipocyte-expressed forkhead transcription factor Foxc2 regulates metabolism through altered mitochondrial function. Diabetes 60, 427-435

27. Seale, P., Lazar, M. A. (2009) Brown fat in humans: turning up the heat on obesity. Diabetes 58, 1482-1484

28. Kajimura, S., Seale, P., Spiegelman, B. M. (2010) Transcriptional control of brown fat development. Cell Metab 11, 257-262

29. Barbatelli, G., Murano, I., Madsen, L., Hao, Q., Jimenez, M., Kristiansen, K., Giacobino, J. P., De Matteis, R., Cinti, S. (2010) The emergence of cold-induced brown 
adipocytes in mouse white fat depots is determined predominantly by white to brown adipocyte transdifferentiation. Am.J.Physiol Endocrinol.Metab 298, E1244-E1253

30. Schulz, T. J., Huang, T. L., Tran, T. T., Zhang, H., Townsend, K. L., Shadrach, J. L., Cerletti, M., McDougall, L. E., Giorgadze, N., Tchkonia, T., Schrier, D., Falb, D., Kirkland, J. L., Wagers, A. J., Tseng, Y. H. (2011) Identification of inducible brown adipocyte progenitors residing in skeletal muscle and white fat. Proc.Natl.Acad.Sci.U.S.A 108, 143-148

31. Seale, P., Kajimura, S., Yang, W., Chin, S., Rohas, L. M., Uldry, M., Tavernier, G., Langin, D., Spiegelman, B. M. (2007) Transcriptional control of brown fat determination by PRDM16. Cell Metab 6, 38-54

32. Kajimura, S., Seale, P., Tomaru, T., Erdjument-Bromage, H., Cooper, M. P., Ruas, J. L., Chin, S., Tempst, P., Lazar, M. A., Spiegelman, B. M. (2008) Regulation of the brown and white fat gene programs through a PRDM16/CtBP transcriptional complex. Genes Dev. 22, 1397-1409

33. Seale, P., Bjork, B., Yang, W., Kajimura, S., Chin, S., Kuang, S., Scime, A., Devarakonda, S., Conroe, H. M., Erdjument-Bromage, H., Tempst, P., Rudnicki, M. A., Beier, D. R., Spiegelman, B. M. (2008) PRDM16 controls a brown fat/skeletal muscle switch. Nature 454, 961-967

34. Scime, A., Grenier, G., Huh, M. S., Gillespie, M. A., Bevilacqua, L., Harper, M. E., Rudnicki, M. A. (2005) $\mathrm{Rb}$ and p107 regulate preadipocyte differentiation into white versus brown fat through repression of PGC-1alpha. Cell Metab 2, 283-295

35. Toh, S. Y., Gong, J., Du, G., Li, J. Z., Yang, S., Ye, J., Yao, H., Zhang, Y., Xue, B., Li, Q., Yang, H., Wen, Z., Li, P. (2008) Up-regulation of mitochondrial activity and acquirement of brown adipose tissue-like property in the white adipose tissue of fsp27 deficient mice. PLoS.ONE. 3, e2890

36. Hansen, J. B., Jorgensen, C., Petersen, R. K., Hallenborg, P., De Matteis, R., Boye, H. A., Petrovic, N., Enerback, S., Nedergaard, J., Cinti, S., te, R. H., Kristiansen, K. (2004) Retinoblastoma protein functions as a molecular switch determining white versus brown adipocyte differentiation. Proc.Natl.Acad.Sci.U.S.A 101, 4112-4117

37. Cederberg, A., Gronning, L. M., Ahren, B., Tasken, K., Carlsson, P., Enerback, S. (2001) FOXC2 is a winged helix gene that counteracts obesity, hypertriglyceridemia, and diet-induced insulin resistance. Cell 106, 563-573

38. Nybroe, O., Rosenkilde, P., Ryttersgaard, L. (1985) Effects of hypophysectomy and substitution with growth hormone, prolactin, and thyroxine on growth and deposition in juvenile frogs, Xenopus laevis. Gen.Comp Endocrinol. 57, 257-265

39. Roy, A. F., Benomar, Y., Bailleux, V., Vacher, C. M., Aubourg, A., Gertler, A., Djiane, J., Taouis, M. (2007) Lack of cross-desensitization between leptin and prolactin signaling pathways despite the induction of suppressor of cytokine signaling 3 and PTP1B. J.Endocrinol. 195, 341-350

40. Lisboa, P. C., Passos, M. C., Dutra, S. C., Bonomo, I. T., Denolato, A. T., Reis, A. M., Moura, E. G. (2006) Leptin and prolactin, but not corticosterone, modulate body weight 
and thyroid function in protein-malnourished lactating rats. Horm.Metab Res. 38, 295299

41. Meyre, D., Delplanque, J., Chevre, J. C., Lecoeur, C., Lobbens, S., Gallina, S., Durand, E., Vatin, V., Degraeve, F., Proenca, C., Gaget, S., Korner, A., Kovacs, P., Kiess, W., Tichet, J., Marre, M., Hartikainen, A. L., Horber, F., Potoczna, N., Hercberg, S., LevyMarchal, C., Pattou, F., Heude, B., Tauber, M., McCarthy, M. I., Blakemore, A. I., Montpetit, A., Polychronakos, C., Weill, J., Coin, L. J., Asher, J., Elliott, P., Jarvelin, M. R., Visvikis-Siest, S., Balkau, B., Sladek, R., Balding, D., Walley, A., Dina, C., Froguel, P. (2009) Genome-wide association study for early-onset and morbid adult obesity identifies three new risk loci in European populations. Nat.Genet. 41, 157-159

42. Nilsson, L., Olsson, A. H., Isomaa, B., Groop, L., Billig, H., Ling, C. (2011) A common variant near the PRL gene is associated with increased adiposity in males. Mol.Genet.Metab 102, 78-81

43. Kok, P., Roelfsema, F., Frolich, M., Meinders, A. E., Pijl, H. (2004) Prolactin release is enhanced in proportion to excess visceral fat in obese women. J.Clin.Endocrinol.Metab 89, 4445-4449

44. Dos Santos Silva, C. M., Barbosa, F. R., Lima, G. A., Warszawski, L., Fontes, R., Domingues, R. C., Gadelha, M. R. (2011) BMI and metabolic profile in patients with prolactinoma before and after treatment with dopamine agonists. Obesity.(Silver.Spring) 19, 800-805

45. Virtanen, K. A., Lidell, M. E., Orava, J., Heglind, M., Westergren, R., Niemi, T., Taittonen, M., Laine, J., Savisto, N. J., Enerback, S., Nuutila, P. (2009) Functional brown adipose tissue in healthy adults. N.Engl.J.Med. 360, 1518-1525

46. Marken Lichtenbelt, W. D., Vanhommerig, J. W., Smulders, N. M., Drossaerts, J. M., Kemerink, G. J., Bouvy, N. D., Schrauwen, P., Teule, G. J. (2009) Cold-activated brown adipose tissue in healthy men. N.Engl.J.Med. 360, 1500-1508

47. Cypess, A. M., Lehman, S., Williams, G., Tal, I., Rodman, D., Goldfine, A. B., Kuo, F. C., Palmer, E. L., Tseng, Y. H., Doria, A., Kolodny, G. M., Kahn, C. R. (2009) Identification and importance of brown adipose tissue in adult humans. N.Engl.J.Med. 360, 1509-1517

48. Saito, M., Okamatsu-Ogura, Y., Matsushita, M., Watanabe, K., Yoneshiro, T., NioKobayashi, J., Iwanaga, T., Miyagawa, M., Kameya, T., Nakada, K., Kawai, Y., Tsujisaki, M. (2009) High incidence of metabolically active brown adipose tissue in healthy adult humans: effects of cold exposure and adiposity. Diabetes 58, 1526-1531

49. Lee, P., Zhao, J. T., Swarbrick, M. M., Gracie, G., Bova, R., Greenfield, J. R., Freund, J., Ho, K. K. (2011) High Prevalence of Brown Adipose Tissue in Adult Humans. J.Clin.Endocrinol.Metab 96, 2450-2455

\section{Figure Legends}


Figure 1. Lack of PRLR impaired HFD-induced obesity in male mice. A: Body weights of $\mathrm{PRLR}^{+/+}(\mathrm{n}=5-9)$ and $\mathrm{PRLR}^{-/-}$mice $(\mathrm{n}=8-9)$ during 16-week time course of standard chow (SC) or high fat diet (HFD). Linear regression was performed for each curve and regression coefficients were compared. B: Representative images of Dual-Energy X ray Absorptiometry (DEXA) analyses in PRLR ${ }^{+/+}$and PRLR ${ }^{-/}$mice under SC or HFD. $C$ : Determination of body fat mass percentage following DEXA analyses $(\mathrm{n}=5-9)$. $D$ : Perirenal, $E$ : gonadal and $F$ : subcutaneaous white adipose tissue (WAT)/Body Weight (BW) ratio were determined on 6mo-old PRLR ${ }^{+/+}(n=5-9)$ and PRLR ${ }^{-/-}(n=8-9)$ mice. Results are expressed as mean \pm SEM of WAT mass (mg)/BW (g) (\%). G: Kidney and $H$ : spleen mass. Results are expressed as mean \pm SEM of tissue mass $(\mathrm{g}),(* \mathrm{p}<0.05, * * \mathrm{p}<0.01, * * * \mathrm{p}<0.001)$

Figure 2. Increased energy expenditure in $\mathrm{PRLR}^{-/-}$mice despite hyperphagia. Metabolic parameters were determined with metabolic cages on 6-mo-old $\mathrm{PRLR}^{+/+}$and $\mathrm{PRLR}^{-/}$males under SC or HFD. A: Food intake (SC) is represented as cumulative ingested Kcal every hour (left panel) or $\mathrm{Kcal} / \mathrm{kg} / \mathrm{h}$ (right panel) $\left({ }^{*} \mathrm{p}<0.05\right) . B: \mathrm{O}_{2}$ consumption is expressed as $\mathrm{ml} / \mathrm{kg}$ for each hour or $\mathrm{ml} / \mathrm{kg} / \mathrm{h}$ (circadian profile, left panels). $C$ : Energy expenditure is expressed as mean $\mathrm{kcal} / \mathrm{kg}$ for each hour or as $\mathrm{kcal} / \mathrm{kg} / \mathrm{h}$ (circadian profile, right panels) $\left({ }^{*} \mathrm{p}<0.05\right)$.

Figure 3. $\mathrm{PRLR}^{-/-}$mice are protected against HFD-induced diabetes. A: Basal glycemia and B: Plasma insulin were measured from 6-mo-old $\mathrm{PRLR}^{-/-}$and $\mathrm{PRLR}^{+/+}$males fasted for $16 \mathrm{~h}$. (n=5-9 per group). $C$ : HOMA-IR and $D$ : HOMA- $\beta$ indexes were determined from basal glycemia and insulinemia as described in Experimental Procedures Section. E: Plasma leptin and $F$ : resistin levels were measured in $\mathrm{PRLR}^{-/-}$and $\mathrm{PRLR}^{+/+}$mice (n=9-10 per group). $(* \mathrm{p}<0.05, * * \mathrm{p}<0.01, * * * \mathrm{p}<0.001)$ 
Figure 4. Emergence of brown adipocytes in white fat depots in $\mathrm{PRLR}^{-/-}$male mice. $A$ : Paraffin-embedded perirenal WAT sections of $\mathrm{PRLR}^{+/+}$and $\mathrm{PRLR}^{-/-}$mice under SC and HFD ( $n=3-5$ per group) were stained with haematoxylin and eosin (H\&E). B: Percentage of BAT in perirenal WAT was assessed with ImageJ software. $C$ : Representative photomicrographs of perirenal WAT sections of UCP1 immunostaining (IHC). D: Western blot analysis of UCP1 in perirenal WAT of $\mathrm{PRLR}^{-/}$HFD fed compared to controls. Thirty $\mu \mathrm{g}$ of proteins were loaded for immunoblotting with specific antibodies raised against UCP1 and GAPDH. Four $\mu \mathrm{g}$ of BAT proteins were used as a positive control (representative illustration of $3 \mathrm{PRLR}^{+/+}$ and $3 \mathrm{PRLR}^{-/-}$WAT). UCP1 infrared fluorescence normalized to that of the GAPDH was determined by densitometry using the Image Studio software (LI-COR) and expressed as fold induction $(* \mathrm{p}<0.05, \mathrm{n}=4-6$ per group). E: Coronal and sagittal FDG-PET slices obtained after a cold stress $\left(45 \mathrm{~min}\right.$ at $\left.6^{\circ} \mathrm{C}\right)$ in $\mathrm{PRLR}^{+/+}$and PRLR ${ }^{-/-} \mathrm{HFD}$ fed mice (see Supplemental Material). Areas of high FDG uptake (standardized uptake value > 2) are represented in orange to white colors.

Figure 5. PRLR controls beige cell transdifferentiation through $\mathrm{pRb}$ signaling. A: Expression of brown fat markers (PRDM16, PGC1 $\alpha, \mathrm{UCP} 1, \mathrm{AdR} \beta 3$ ) and of adipocyte differentiation genes (ZFP423, C/EBP,$P P A R \gamma 2$ and SREBP1), normalized to $18 \mathrm{~S}$ mRNA levels, were quantified by qPCR in perirenal WAT of 6 mo-old male mice from both genotypes $(n=8-10)$. $B: p R b$ and Foxc2 mRNA levels were determined by qPCR in perirenal WAT. FoxC2 expression was significantly lower in $\mathrm{PRLR}^{-/}$mice under SC. $\quad\left(* \mathrm{p}<0.05,{ }^{*} \mathrm{p}<0.01\right.$, $* * * \mathrm{p}<0.001, \mathrm{n}=8-10$ per group). 


\section{Table 1. Primer Sequences of Genes Analyzed in quantitative RT-PCR}

The abbreviations of the genes, their GENBANK or NCBI accession number and 5'- to 3'- nucleotide sequences of the sense and antisense primers are presented.

\begin{tabular}{|c|c|c|c|c|}
\hline Name & Accession number & Amplicon & Sense primer & Antisense primer \\
\hline $18 \mathrm{~S}$ & X00686 & 66 bp & CCCTGCCCTTTGTACACACC & CGATCCGAGGGCCTCACTA \\
\hline PRDM16 & NM_027504 & $78 \mathrm{bp}$ & CTTCTCCGAGATCCGAAACTTC & GATCTCAGGCCGTTTGTCCAT \\
\hline PGC-1 $\alpha$ & AF049330 & $162 \mathrm{bp}$ & CCCAGGCAGTAGATCCTCTTCAA & CCTTTCGTGCTCATAGGCTTCATA \\
\hline UCP1 & ВC01270 & $150 \mathrm{bp}$ & GCCAAAGTCCGCCTTCAGAT & TGATTTGCCTCTGAATGCCC \\
\hline $\operatorname{AdR} \beta 3$ & NM_013462 & $150 \mathrm{bp}$ & TGCGCACCTTAGGTCTCATTAT & AAGGCGGAGTTGGCATAGC \\
\hline ZFP423 & NM_033327 & 95 bp & CCCCCTGATGGGAATAATGC & GCAATGCGCCTGTTGGA \\
\hline $\mathrm{C} / \mathrm{EBP} \alpha$ & NM_007678 & $116 \mathrm{bp}$ & CGCAAGAGCCGAGATAAAGC & CAGTTCACGGCTCAGCTGTTC \\
\hline PPAR $\gamma 2$ & U09138 & $161 \mathrm{bp}$ & GCATCAGGCTTCCACTATGGA & AAGGCACTTCTGAAACCGACA \\
\hline SREBP1 & NM_011480 & $83 \mathrm{bp}$ & CGGCCССТTCССТСТАСТC & AGATACCACGATTGTTTTGGAAGTG \\
\hline $\mathrm{pRb} 1$ & NM_009029 & 89 bp & CTGGCCTGTGCTCTTGAAGTT & CCACGGGAAGGACAAATCTGT \\
\hline Foxc2 & NM_013519 & $120 \mathrm{bp}$ & TCCATGGGAACCTTCTTCGA & GATCTCAAACTGAGCTGCGGATA \\
\hline
\end{tabular}

\section{Supplemental Fig. S1.}


Measurement of ambulatory movements is expressed as number of counts for each hour (circadian profile, left panel) or as mean counts/hour (right panel). No significant difference was observed between genotypes.

\section{Supplemental Fig. S2.}

Adipocytes are smaller in $\mathrm{PRLR}^{-/-}$mice. (A) Representative micrographs of paraffinembedded gonadal WAT sections (x 200) from PRLR $^{+/+}$and $\mathrm{PRLR}^{-/-}$mice under SC and HFD. These sections were stained with haematoxylin and eosin (H\&E) and adipocyte size was determined from subcutaneous (B) and gonadal (C) WAT by using the ImageJ software. Results are mean \pm SEM of at least 150 determinations per animal $\left(* \mathrm{p}<0.05,{ }^{*} \mathrm{p}<0.01, \mathrm{n}=5\right.$ per group).

Supplemental Fig. S3. Brown Fat-like cell development is depot-specific in $\mathrm{PRLR}^{-/-}$mice. Expression of brown adipocytes (PRDM16 and $U C P 1)$ and adipocyte differentiation genes $(P P A R \gamma 2, Z F P 423$ and $C / E B P \alpha)$ was measured by qPCR in subcutaneous (A) and gonadal (B) WAT of $\mathrm{PRLR}^{+/+}$and $\mathrm{PRLR}^{-/-}$mice under HFD. Under HFD, brown fat marker expression is decreased in gonadal but not in subcutaneous WAT of $\mathrm{PRLR}^{-/-}$mice compared with PRLR ${ }^{+/+}$animals $\left({ }^{*} \mathrm{p}<0.05,{ }^{* *} \mathrm{p}<0.01, \mathrm{n}=8-10\right.$ per group). 